\title{
Study on the Vegetative Propagation Through Cuttings of Mentha $x$ piperita Hybrid using Various Rooting Substrates
}

\author{
Erzsebet BUTA ${ }^{1)}$, Maria CANTOR ${ }^{(*)}$, Denisa HORT ${ }^{1)}$ and Mihai BUTA ${ }^{2)}$ \\ ${ }^{1)}$ Department of Horticulture and Landscaping. University of Agricultural Sciences and Veterinary \\ Medicine, Cluj-Napoca. \\ ${ }^{2)}$ Department of Technical Sciences and Soil Sciences. University of Agricultural Sciences and Veteri- \\ nary Medicine, Cluj-Napoca. \\ ${ }^{*}$ Corresponding author, e-mail: marcantor@yahoo.com
}

Bulletin UASVM Horticulture 71(2) / 2014

Print ISSN 1843-5254, Electronic ISSN 1843-5394

DOI:10.15835/buasvmcn-hort:10511

\begin{abstract}
The growing demand for seasoning plants and aromatic herbs on the Romanian market led to the implementation of new research on the improvement of propagation technology. Mentha x piperita was chosen for the classical propagation, a plant used not only in the food industry and in the alternative medicine, but also as an ornamental plant in the rustic gardens. It is also used with great success for decorating terraces and balconies. It is part of the compositions made for kitchens, along with other seasoning plants. The aim of the research was to improve the multiplication of Mentha x piperita hybrid. During the experiences were studied the following: the influence of the substrate on the rooting of cuttings and the influence of substrate on growth and development of plants. Recorded data were interpreted statistically by variance analysis. Results showed that the rooting process were different and depends on the substrate. Mentha x piperita has rooted in perlite in 15 days, in peat with perlite in 20 days and in peat mixed with sand in 25 days. The number of shoots was not influenced by the substrates under study. The root system best developed in the substrate composed of peat and perlite.
\end{abstract}

Keywords: mint, multiplication, peat, perlite, sand

Introduction. Mentha x piperita is a natural hybrid, a cross between Mentha aquatica and Mentha spicata. This hybrid indigenous to England is widespread throughout all regions of the world. Because mint is a hybrid, it is usually sterile, with no possibility of fruition and the propagation can be either vegetative or in vitro (Lawrence, 2007; Ghanti, 2003). It was and it is grown mainly for medicinal purposes (Toma, 2009; Draghia and Chelariu, 2011). This species was cultivated for the first time in England in 1760 from where it spread in our country as well. In Romania the first crop of mint was founded in 1908 in Cluj Napoca. After 21 years it began to be cultivated for industrial purposes. Today it enjoys a wide use in various fields such as medicine, cosmetic industry, pharmaceutical industry, food industry and culinary art.
Aims and objectives. The purpose of this study was to improve the propagation technology of the Mentha x piperita natural hybrid. The objectives of this research were the study of the rooting degree; the influence of the substrate on rooting cuttings; the influence of the substrate on the growth and development of plants.

Materials and Methods. The experiments on the improvement of the propagation technology of Mentha x piperita hybrid were conducted in the period 2012-2013 within the greenhouse of the Floriculture Department of the University of Agricultural Sciences and Veterinary Medicine Cluj-Napoca. Three rooting substrates were tested: perlite, Klasmann TS3 peat + perlite, Klasmann TS3 peat + sand (1:1 ratio). The average temperature of substrate was between $20.9-21.7^{\circ} \mathrm{C}$ and the propagation environment temperature 
Tab. 1 Centralized table concerning the rooting process of Mentha x piperita

\begin{tabular}{cccc}
\hline Studied substrates & Data of preparation cuttings & Data of rooting & \multicolumn{2}{c}{ Days of rooting process } \\
\hline Perlite & 15.06 .2013 & 30.06 .2013 & 15 \\
\hline Klasmann TS3 peat + perlite & 15.06 .2013 & 05.07 .2013 & 20 \\
\hline Klasmann TS3 peat + sand & 15.06 .2013 & 10.07 .2013 & 25 \\
\hline
\end{tabular}

Tab. 2 Unilateral influence of substrate on length of roots, number of leaves, diameter of rosette and number of shoots at Mentha x piperita cuttings

\begin{tabular}{ccccccc}
\hline \multirow{2}{*}{ Studied substrates } & \multicolumn{3}{c}{ Length of roots (cm) } & \multicolumn{3}{c}{ Number of leaves (piece) } \\
\cline { 2 - 7 } & Relative & $\begin{array}{c}\text { Absolute } \\
(\%)\end{array}$ & $\begin{array}{c}\text { Signification } \\
\text { of differences }\end{array}$ & Relative & $\begin{array}{c}\text { Absolute } \\
(\%)\end{array}$ & $\begin{array}{c}\text { Signification of } \\
\text { differences }\end{array}$ \\
\hline Perlite & 11.79 & 102.1 & 0.24 & 13 & 112.9 & $1.49^{* *}$ \\
\hline $\begin{array}{c}\text { Klasmann TS3 peat + } \\
\text { perlite }\end{array}$ & 13.4 & 116 & $1.85^{* *}$ & 10.15 & 88.1 & $-1.37^{0}$ \\
\hline Klasmann TS3 peat + sand & 9.62 & 83.3 & $-1.93^{0}$ & 11.4 & 99 & -0.11 \\
\hline Average of experience (C) & 11.55 & 100 & Mt. & 11.52 & 100 & Mt. \\
\hline
\end{tabular}

DL (p 5\%) 0.97, DL (p 1\%) 1.78, DL (p 0.1\%) 3.95; DL (p 5\%) 0.64, DL (p 1\%) 1.18, DL (p 0.1\%) 2.62

\begin{tabular}{ccccccc}
\hline \multirow{2}{*}{ Studied substrates } & \multicolumn{3}{c}{ Diameter of rosette $(\mathrm{cm})$} & \multicolumn{3}{c}{ Number of shoots (piece) } \\
\cline { 2 - 7 } & Relative & $\begin{array}{c}\text { Absolute } \\
(\%)\end{array}$ & $\begin{array}{c}\text { Signification } \\
\text { of differences }\end{array}$ & Relative & $\begin{array}{c}\text { Absolute } \\
(\%)\end{array}$ & $\begin{array}{c}\text { Signification of } \\
\text { differences }\end{array}$ \\
\hline Perlite & 7.89 & 97.8 & -0.18 & 2.5 & 88.3 & -0.33 \\
\hline $\begin{array}{c}\text { Klasmann TS3 peat }+ \\
\text { perlite }\end{array}$ & 8.8 & 109 & $0.73^{*}$ & 1.5 & 53 & -1.33 \\
\hline Klasmann TS3 peat + sand & 7.54 & 93.4 & $-0.53^{\circ}$ & 4.5 & 159 & 1.67 \\
\hline Average of experience (C) & 11.2 & 100 & Mt. & 2.83 & 100 & Mt. \\
\hline
\end{tabular}

DL (p 5\%) 0.83, DL (p 1\%) 1.53, DL (p 0.1\%) 3.40; DL (p 5\%) 2.12, DL (p 1\%) 3.89, DL (p 0.1\%) 5.63

was $22.4^{\circ} \mathrm{C}$. The combined analyzed factors resulted in six experimental variants, arranged in randomized blocks in three replications. There were made 20 stem cuttings for each replicates which were treated with Radistim for a better rooting. The cutting length was $7 \mathrm{~cm}$. The control was the average of experiment.

Results and Discussion. Mentha $x$ piperita has rooted in perlite in 15 days, in peat with perlite in 20 days and in peat mixed with sand in 25 days (Table 1). The longest cuttings were formed in the substrate composed of peat and perlite. A great number of leaves were recorded in perlite. It was observed that the best results of the rosette diameter were recorded in peat + perlite. The number of shoots was not influenced by the substrates under study. The root system best developed in the substrate composed of peat and perlite (Table 2).
Conclusion. In the present research work, it has been shown that Mentha $x$ piperita roots relatively quickly in perlite, but the longest root system is formed in the peat and perlite substrate. The results describe a rapid rooting in aerated substrate. The growth and development of the plants are particularly ensured in the peat and sand mixture.

\section{References}

1. Draghia L and Chelariu E.L (2011). Floricultură. Ed. Ion Ionescu de la Brad Iași.

2. Ghanti K, Kaviraj CP, Venugopal RB, Jabeen FTZ and Srinath Rao (2003). Rapid regeneration of Mentha piperita L. from shoot tip and nodal explants, Indian Journal of Biotech 3:594-598.

3. Lawrence BM (2007). Mint: The genus Mentha. Taylor and Francis Group, Boca Raton, Florida.

4. Toma F (2009). Floricultură și Artă florală, Specii utilizate ca plante în ghivece pentru decorul interioarelor. Vol. 3. Editura Invel Multimedia, București. 